\title{
bioentrepreneur
}

\section{IP/Technology Transfer}

Published online: 29 January 2003, doi:10.1038/bioent710

$\checkmark$ Commercializing biotechnology in the UK

Susan Searle ${ }^{1}$, Brian Graves ${ }^{2}$ \& Chris Towler ${ }^{3}$

Susan Searle is managing director, Imperial College Innovations Ltd.,

London.

Brian Graves is head of physical sciences, Imperial College Innovations Ltd., London.

Chris Towler is director of strategy development, Imperial College, London.

\section{In only five years, the technology transfer arm of Imperial College has} launched over 50 companies.

Almost a quarter of all European biotechnology companies are located in the United Kingdom. Despite the maturity of UK biotechnology, universities seeking to license intellectual property or use it as the basis for a new life science venture still face several challenges in finding the relevant expertise and creating a fertile environment to facilitate startup activity. Imperial College Innovations Limited (ICIL; now Imperial Innovations) was set up by London University's Imperial College to provide practical advice and assistance to entrepreneurial scientists wishing to commercialize a promising research discovery. In the following article, we discuss the strategy adopted by Imperial Innovations that has enabled Imperial College to spin out over 50 new companies in the past five years.

\section{Building on excellence}

London University's Imperial College is ranked among the world's leading research-based universities in its chosen fields of science, engineering, and medicine. The college's founding charter of 1907 declared that its focus should be on research "especially in its application to industry," and that focus remains part of its mission today, encompassing the application of research not just to industry, but to commerce and healthcare, too.

Over the past five years, Imperial has mounted a determined effort to capitalize on its intellectual assets and skills in a variety of ways. As part of this program, it created a subsidiary company, Imperial Innovations, that has established and nurtured many new ventures, with new companies being generated at a rate of around one per month.

Over 30 of these companies are in the pharmaceutical and life science sector. A number have reached later stage, including Sterix (Oxford Science Park, Oxford), Microscience (Wokingham, UK), Lorantis (Cambrdige, UK), Adaptive Screening (Harston, UK), and Argenta (Harlow, UK). The rest are working their way through the earlier stages; the more advanced of these include PhotoBiotics (London), Gene Expression Technologies (London), Neurotherapies (London), and PolyTherics (London).

The success of commercial exploitation at Imperial College depends on a wide range of factors, including culture, motivation, and the availability of finance and facilities. This process is continuing to evolve rapidly and reflects the "hands on" nature of Imperial Innovations' support and its determination to ensure that its technology gets developed and generates a return to all parties.

\section{Deciding to commercialize}

The first step in commercialization is for someone to recognize that something significant has been invented. Then, Imperial Innovations has to be made aware of it. Many academics will initiate this step themselves, but others need to be

encouraged to think about whether this is a path they wish to tread. This encouragement can come from Imperial

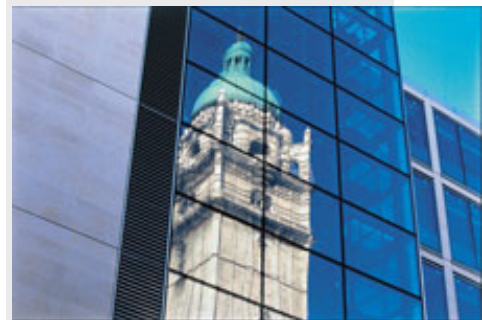

Photographer: Jan Chlebik Making capital: Imperial College's technology transfer arm, Imperia Innovations, has dramatically rearch discoveries at the university. 
Innovations staff networking with academics; in other cases, colleagues and students have been catalysts. In no case is there undue pressure on an academic to start on the commercialization path if they are not motivated to do so or have other intentions for their innovative discoveries.

Once the invention has been disclosed to Imperial Innovations, there is a need to identify the innovative step and understand its potential. Success depends on knowing whether there is a market opportunity for the technology, and here the commercial acumen of the Imperial Innovations technology transfer executive plays a major role because the market knowledge and product definition is often very sketchy at this stage.

Imperial Innovations is organized into four technology teams, two of which are devoted to medicine and life sciences. These teams have a mix of invaluable skills, including expertise in intellectual property assessment, conduct of due diligence, market research, and business development and licensing. To complement these in-house skills, consultants may be engaged, using Imperial College's own seed fund, to carry out a preliminary market study and prepare a draft business plan for the exploitation of the technology.

\section{Intellectual property protection}

Development of an intellectual property base and strategy is vital to successful commercialization. A key task is to identify the inventors and contributors to the technology and ensure that ownership is clear.

Working out who did what, and when, often requires extensive due diligence, particularly given the tendency of research institutes to collaborate and co-invent. This process can also be facilitated by supervising a search of the prior art as well as providing advice on how to support and maintain appropriate intellectual property protection. Another part of this process is to assess the extent of commercial opportunity for the intellectual property.

Imperial College takes great care to ensure that all inventors are rewarded equitably for their contributions. Inventors normally receive a share of royalties earned through license deals or get an equity stake in a spin-out company.

\section{Commercialization route}

Having established that there is a market for the technology and identified the intellectual property ownership, Imperial Innovations will file patents and advise on the commercialization strategy for the technology.

There are many considerations in choosing between creating a spin-out company or licensing the technology, including the size and geographical scale of the market to be addressed, entry points to the market, development times, and resources needed to create a product. The business plan is a key guide to this decision, but so too is networking with industrial and financial contacts to ensure that all key factors are identified and addressed at an early stage.

Imperial Innovations takes a very active role in marketing and negotiating licensing agreements. Again, an established network of industrial contacts facilitates this, but we also research the relevant market to direct this effort. Market knowledge is also necessary to understand the potentia value of the technology and ensure that the terms of the license will enable the technology to be brought to market in a timely and effective way.

\section{Forming a spin-out}

Having decided to form a spin-out company, Imperial Innovations will work with the inventors to agree on the structure of the company, its strategy, and its management needs. The formation process calls on a mature knowledge of business management issues and concepts, such as equity structure, corporate governance, and business finance, which will often be new and unfamiliar to academic founders.

To facilitate this process, Imperial Innovations has initiated an Entrepreneurs' Programme, in collaboration with the College's Entrepreneurship Centre, that provides instruction on such topics. The program consists of seminars and workshops that aim to enable entrepreneurs, both aspiring and seasoned, to develop the necessary management skills and knowledge.

The company formation process represents a time of transition for the founding team during which they assume a high level of responsibility for the management of their company amongst the new board of directors. Academic founders will usually be involved in recruiting board members $w$ ith the necessary skills to commercialize the inventions.

The transition from academic to entrepreneur can also lead to conflicts with college duties. At Imperial College, the decision to create a spin-out company has to be formally approved by the college. Before approval, the college considers the business plan, the equity split between the founders and the college, the management structure, funding, and the roles and duties of the founders in the company. A key emphasis is placed on ensuring that academic founders are helped to balance their time between working with their companies and continuing to engage in world-class research, publication, and teaching within the college. 
When a company is formed, there are a number of key legal documents to be created and decisions to be made on tax, financial structures, and insurance. Imperial Innovations has access to a range of professional service providers who give advice on such matters on preferential terms.

Experience has shown that this form of assistance is of considerable advantage to founders because it removes the burden of seeking such help in an area that is highly specialized and dependent on establishing strong working relationships that will last for the life of the company.

\section{Pre-funding management}

When a company is formed, Imperial Innovations is usually a significant shareholder and will have agreed to appoint a director to the board. The key management issues facing a spin-out company at this stage will be creating a prototype product or achieving a measure of proof of concept for the technology within the limits of the seed funding available.

Assuming the early development program is successful, attention will then switch to seeking first-round finance. Imperial Innovations has developed strong connections with venture capitalists, business "angels," corporate funds, and other sources of finance, and it facilitates matching the appropriate finance sources with the needs of the spin-out. The company itself $w$ ill be responsible for negotiating terms $w$ ith the financing organization, but as a major shareholder, Imperial Innovations is also involved.

In addition, Imperial Innovations assists startups by organizing investor networking events, where spin-out companies have the opportunity to present their business plans and funding needs to the finance community and to participate in informal networking with a view to exploring potential partnerships for the future

\section{Post-funding management}

When first-round funding is concluded, the management structure, strategic focus, and resource requirements start to change significantly. Usually, a full-time CEO or commercial manager or both will be appointed, and the strategy shifts away from prototype development to actively seeking customers and implementing a commercialization and manufacturing strategy. For some companies, licensing may be the preferred route to market and the commercial team will be devoted to seeking industrial partners and agreeing on licenses.

Imperial Innovations' role in the day-to-day management also diminishes and as further funding rounds are achieved, its equity stake will fall to the point that it relinquishes its position on the board.

\section{Conclusions}

In summary, what are the ingredients for success for an Imperial College spin-out? Clearly, there is no magic recipe, but the following factors are key

- A culture that encourages and nurtures entrepreneurship

- Strong management team and company board

- Clear business plan with realistic targets that can be met before cash runs out

- Route to market identified and costs covered

- Competition identified and assessed

- Valuable accessible market

- Credible business and revenue model

- Technology that provides customer benefits

- Cutting-edge technology that is well protected

Imperial's success in encouraging entrepreneurship reflects Imperial Innovations' focus on facilitating the many different steps in the growth and development of a biotechnology venture from a promising scientific discovery (see Imperial business). In short, Imperial Innovations plays multiple roles (advisor, participant, board member, and intermediary) in fostering relationships between the different partners-management, investors, researchers, and university institutions-necessary for building a successful life science venture. See Table 1. 


\begin{tabular}{|l|l|}
\hline Company & Web address \\
\hline Adaptive Screening (Harston, UK) & http://www.adaptive-screening.com/ \\
\hline Amedis Pharmaceuticals (Cambridge, UK) & http://www.amedis-pharma.com/ \\
\hline Argenta Discovery (Harlow, UK) & http://www.argentadiscovery.com/ \\
\hline Biogeny (parent company of Impyx; London) & http://www.biogeny.co.uk/ \\
\hline DeltaDOT (London) & http://www.deltadot.com/ \\
\hline Gene Expression Technologies (London) & http://www.gextec.com/ \\
\hline Lorantis Holdings (Cambridge, UK) & http://www.lorantis.co.uk/ \\
\hline Metabometrix (London) & http://www.metabometrix.com/ \\
\hline Microscience (Wokingham, UK) & http://www.microscience.com/ \\
\hline Photobiotics (London) & http://www.photobiotics.com/ \\
\hline Proteom (Cambridge, UK) & http://www.proteom.com/ \\
\hline
\end{tabular}

\section{Box 1: Imperial business}

To date, Imperial Innovations has launched over 50 startups. A small selection of Imperial College spin-out companies operating in the biotechnology, pharmaceutical, and life-science sector are listed in Table 1.

\section{Box 2: Glossary}

Prior art: Existing patents and publications related to your invention that will enable determination of whether it is novel and can thus be registered.

Due diligence: A thorough analysis of the scientific, public, and patent literature for information relating to an invention that can highlight any technical or legal pitfalls and identify ways you can protect your intellectual property.

\section{Web links}

Encyclopedia of Life Sciences

$\rightarrow$ http://www.els.net/els/subscriber/home/default.asp?

sessionid $=8 \mathrm{ca} 7 \mathrm{a} 0683 \mathrm{~d} 85 \mathrm{fb} 2 \mathrm{e}$

Patenting genes and their products

\section{SPRINGER NATURE}

(C) 2019 Nature is part of Springer Nature. All Rights Reserved.

partner of AGORA, HINARI, OARE, INASP, ORCID, CrossRef, COUNTER and COPE 